\title{
Correspondence
}

To the Editor:

\section{NEUROPATHOLOGISTS: ANOTHER BYPRODUCT OF NEUROSURGERY AT THE TORONTO GENERAL}

In Dr. Findlay's delightful historical review of neurosurgery at the Toronto General Hospital, ${ }^{1}$ the (unnamed) gentleman in the very centre of Figure 1, between Dr. Mary Tom and Professor Eric Linell is, of course, the late Professor Jerzy Olszewski, who after stints in matters neuroanatomical at the Montreal Neurological Institute and at Saskatoon became Eric Linell's successor at the Toronto General, and Canada's pre-eminent and most beloved Neuropathologist.

The twice-weekly brain cutting sessions held by Olszewski at the "TGH" through the late 50's and early 60's were avidly attended by many of Kenneth McKenzie's neurosurgical disciples (and many neurologists also), leading to the most spirited clinicopathological debates.

Even after retirement, Professor Linnell would drop in to the Banting Neuropathology lab for afternoon tea and scientific discourse. Both Dr. Mary Tom and Professor "George" Olszewski have been memorialized by annual Lectureships at the Canadian Association of Neuropathologists' meeting.

Influenced by the lively interchange between the clinical neuroscientists and the pathologists, an impressive wave of Neuropathologists passing through the Toronto General fanned out across much of Canada (Rewcastle to Calgary, Dolman and Berry to Vancouver) and beyond (Ken Earle to Washington, Peter Lampert to San Diego). Those students of neuropathology who worked at "the General" in those years consider ourselves a most fortunate bunch!

M.J. Ball, M.D.

Oregon Health Sciences University Portland, Oregon

1. Findlay JM. Neurosurgery at the Toronto General Hospital, 1924-1990: Part 1. Can J Neurol Sci 1994; 1 : 146-158.
Reply from the author:

\section{HISTORY OF NEUROSURGERY AT THE TORONTO GENERAL HOSPITAL - PART I}

I appreciate Dr. Ball's interest in the History of Neurosurgery at the Toronto General Hospital, and his comments on Dr. George Olszewski. I am indebted to Drs. Wherrett and Rewcastle, who have been able to identify the individuals in Figure 1 (please see the following letter).

\section{J. Max Findlay, M.D.} Edmonton, Alberta

\section{To the Editor:}

Figure 1 of Max Findlay's superb history of neurosurgery at the Toronto General Hospital ${ }^{1}$ highlights the vital role that neuropathology has played in the development of neurosurgery, neurology and neuroradiology at the hospital.

This picture, which probably was displayed in the Division of Neuropathology at the Banting Institute for many years, will be familiar to many former residents. Lois Lloyd, who is third from the left in the picture, confirmed to me that it was taken in 1951-52 and that those in the picture from the left are, Dr's. Hyland, Tom, Lloyd, Wollin and Linell. Dr. Lloyd was a fellow with Dr. Richardson who went on to train in neuro-ophthalmology with Frank Walsh and is currently a member of the Department of Ophthalmology at The Toronto Hospital. Dr. Delbert Wollin was the second neuroradiologist at the hospital. ${ }^{1} \mathrm{He}$ went on to Queen's University in Kingston. The individual identified by Dr. Ball was Wollin, not Olszewski.

J.R. Wherrett, M.D.

Toronto, Ontario

1. Findlay JM. Neurosurgery at the Toronto General Hospital, 1924-1990: Part I. Can J Neurol Sci 1994; 21: 146-158.

\section{Books Received}

AFFECT REGULATION AND THE ORIGIN OF THE SELF. 1994. By Allan N. Schore. Published by Lawrence Erlbaum Associates, Inc. 670 pages. $\$ 189 \mathrm{Cdn}$. approx.

ANATOMICAL GUIDE FOR THE ELECTROMYOGRAPHER. THIRD EDITION. 1994. By Aldo O. Perotto. Published by Charles C. Thomas. 309 pages. $\$ 64 \mathrm{Cdn}$. approx.

AN INTRODUCTION TO NEUROENDOCRINOLOGY. 1994. By Richard E. Brown. Published by Cambridge University Press. 408 pages. $\$ 112 \mathrm{Cdn}$. approx.

CURRENT MANAGEMENT OF CEREBRAL ANEURYSMS. 1994. By AANS Publications Committee. Edited by Issam A. Awad. Published by American Association of Neurological Surgeons. 327 pages. \$126 Cdn. approx.

INTERACTIVE IMAGE-GUIDED NEUROSURGERY. 1994. By AANS Publications Committee. Edited by Robert J. Maciunas. Published by American Association of Neurological Surgeons. 278 pages. $\$ 126 \mathrm{Cdn}$. approx.
MANUAL OF NERVE CONDUCTION VELOCITY AND CLINICAL NEUROPHYSIOLOGY. THIRD EDITION. 1994. By J. DeLisa, H.J. Lee, E.M. Baran, K-S. Lai and N. Spielholz. Published by Raven Press. 508 pages. $\$ 67 \mathrm{Cdn}$. approx.

RECEPTORS. 1994. By Richard M. Restak. Published by Bantam Canada. 228 pages. $\$ 42 \mathrm{Cdn}$. approx.

SCIENCE AND PRACTICE IN CLINICAL NEUROLOGY. 1994. Edited by S.C. Gandevia, D.J. Burke and M. Anthony. Published by Cambridge University Press. 453 pages. $\$ 84 \mathrm{Cdn}$. approx.

SPATIAL VISION IN HUMANS AND ROBOTS. 1994. Edited by Laurence Harris and Michael Jenkin. Published by Cambridge University Press. 448 pages $\$ 84 \mathrm{Cdn}$. approx. 